\title{
Dictyostelium discoideum as a pharmacological model system to study the mechanisms of medicinal drugs and natural products
}

\author{
JUDITH SCHAF", JOSEPH DAMSTRA-ODDY\# and ROBIN S.B. WILLIAMS* \\ Centre for Biomedical Sciences, Department of Biological Sciences, Royal Holloway University of London, UK.
}

\begin{abstract}
Developing novel compounds for the treatment of diseases remains one of the highest priorities in biomedical research, where it is critical to identify their targets and how they work at a cellular level. Most studies in this area employ mammalian models, since rodents or non-human primates are seen as a good approximation for humans. However, using mammalian models can be problematic for a range of reasons, including high genetic redundancy and the essential role for many proteins in development. More importantly, it is very difficult to identify how compounds function at a cellular or molecular level in these models without a previously suggested mechanism or target. So how can we identify targets of medicinal compounds? In this review we outline the use of an innovative and tractable model system, Dictyostelium discoideum, to provide useful insight to the cellular and molecular functions of both therapeutic drugs and pharmacologically active natural products. We outline the advantages of using this model, and then provide a range of exemplar studies using $D$. discoideum in pharmacological research to demonstrate breakthroughs in understanding the action and effects of compounds, and the subsequent translational of these advances to mammalian models leading to potential improvements in societal health.
\end{abstract}

KEY WORDS: mechanism of action, natural product, drug discovery, pharmacogenomics, pharmacology

\section{Introduction}

Dictyostelium discoideum is a soil-living eukaryotic amoeba that was first described in 1935. D. discoideum employs two mutually exclusive life cycles - initially under optimal nutrient conditions existing in a unicellular state consuming bacteria as a food source and multiplying via mitotic cell division (Li and Purugganan, 2011). However, under starvation conditions, cells enter a development life cycle, where they migrate together and form multicellular structures called fruiting bodies. During this aggregation phase, cells initiate a process of differentiation where two distinct cell types are formed.

In the following sections we will introduce $D$. discoideum as a pharmacological research model. We will highlight the characteristics of the model that facilitate its use in this research area, including specific methodologies and approaches that are rapidly employable in the system. We will then outline a range of studies, relating to both pharmaceutical drugs and potential therapeutic natural products, where $D$. discoideum has been used as a research model to advance our understanding of their cellular mechanisms and targets. We will also outline subsequent translational work to validate these discoveries in mammalian models or in humans.

\section{Pharmacological model systems and the social amoeba D. discoideum}

The field of pharmacology focuses on understanding the action of drugs (and natural products) at a molecular, cellular, or organ-

Abbreviations used in this paper: AplD, amoebapore-like protein D; DAG, diacylglycerol; DGKA, diacylglycerol kinase; EGGG, epigallocatechin gallate; ERK1/ERK2, extracellular signal-regulated kinase 1/2; GSK3, glycogen synthase kinase 3; MCT, medium-chain triglyceride; MAPK, mitogen-activated protein kinase; MDCK, Madin-Darby Canine Kidney; mTOR, mechanistic target of rapamycin; $\mathrm{PIP}_{3}$, phosphoinositide trisphosphate; PI3K, phosphoinositide 3-kinase; PKA, protein kinase A; PKC, protein kinase C; PKD2, polycystic kidney disease 2; PPK1, polyphosphate kinase 1 ; PP2A, protein phosphatase $2 \mathrm{~A}$; psrA, regulatory subunit of PP2A; QSAR, quantitative structure-activity relationship; SAR, structure-activity relationship; S-1-P, sphingosine-1-phosphate; TPC, two-pore channel; TRPP2, transient receptor potential cation channel; VPA, valproic acid.

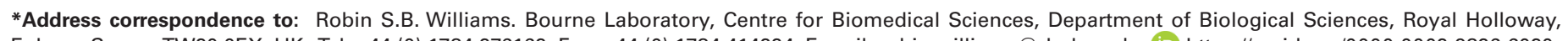

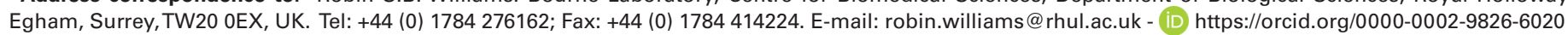

\#Note: the indicated authors contributed equally. 


\section{A}

\section{Screening a $D$. discoideum mutant library for compound-resistant}

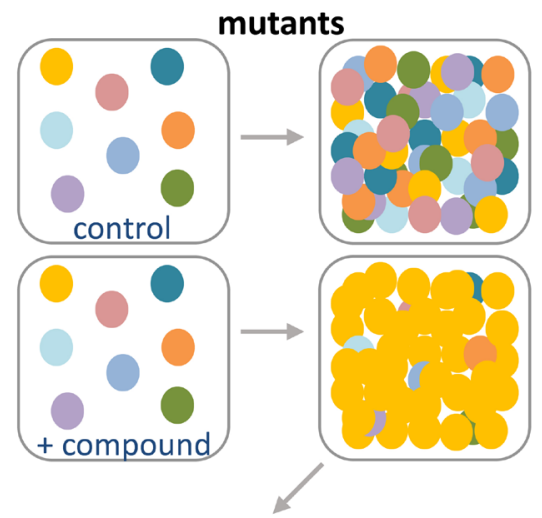

\section{Rapidly remaking the gene knockout} by CRISPR/Cas9

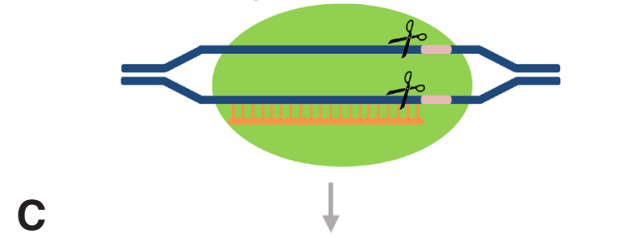

Assessing resistance to compound

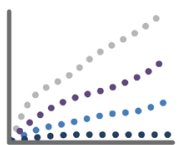

Growth

assays

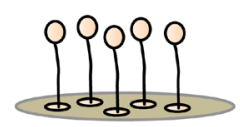
assays
Development

Fig. 1. D. discoideum as a pharmacological model. Identifying molecular mechanisms and potential primary targets of medicinal drugs or bioactive natural compounds in D. discoideum can employ a standard experimental workflow. (A) Providing a compound reduces cell growth at physiological relevant concentrations, a library of mutant cells (represented by different coloured circles) can be grown in the presence of the compound. Resistant mutants (yellow) can be isolated and the mutated gene responsible for the resistance can be rapidly identified. (B) The target gene must be ablated in wild type cells, through homologous recombination of a knockout cassette or through CRISPR/Cas9 (pictured). (C) The resistant phenotype can then be confirmed, using growth or development assays.

ismal level, and the development of new therapeutic treatments. Research in this area is especially relevant for the treatment of diseases, including for example cancer, epilepsy and Alzheimer's disease where current treatments may not be effective (Laugsand et al., 2011, Yiannopoulou and Papageorgiou, 2013), or may give rise to resistance or cause severe adverse effects (Gaitatzis and Sander, 2013, Kelland, 2007). Thus, understanding the mechanisms of action of current treatments, and the development of new medications remains a research priority. Although animal models provide the industry standard for these studies, it remains highly problematic to identify a drug target in these models without some prior insight to specific targets or mechanisms. Animal-based research approaches are also complicated by the innate complexity of mammalians systems with multiple variants of many proteins present in widely ranging cell types, and due to metabolism and pharmacokinetics considerations. Thus, new and innovative approaches are needed to help identify drug targets and mechanisms.

Non-animal models have long been employed as innovative, fast, and cost-effective systems for research, often providing fundamental breakthroughs in understanding cellular functions in mammalian systems. These systems traditionally include yeast and fungi, but a range of recent studies have illustrated that $D$. discoideum can now be added to this list (MullerTaubenberger et al., 2013, Williams et al., 2006). A wide variety of characteristics support the use of $D$. discoideum as an advantageous model for this research. Phylogenetic analysis indicates that $D$. discoideum is more closely related to animals than to plants or bacteria, and contains many orthologues of human proteins that have been lost in yeast (Eichinger et al., 2005), including a range of proteins linked to disease-related processes (Muller-Taubenberger et al., 2013, Williams et al., 2006). Thus, the simple compact genome of $D$. discoideum, with less functional redundancy compared to mammalian cells, provides a useful model for research. In addition, a range of experimental procedures are available in $D$. discoideum that are difficult or impossible in mammalian systems. The haploid nature of $D$. discoideum has allowed the creation of genome wide mutant libraries, which contain thousands of individual mutants having each lost a single gene (Paschke et al., 2018). These libraries can be used to identify mutants with reduced sensitivity to medicinal compounds (Fig. 1), thus suggesting that the encoded proteins are either potential targets or function to revert key changes in drug-sensitive signalling pathways. Mutants that are resistant to a specific compound can be rapidly recapitulated by using either homologous integration of knockout cassettes (Paschke et al., 2018) or CRISPR/Cas9 techniques (Sekine et al., 2018). In these cases, cell growth can provide an effective and rapid means to measuring sensitivity to a compound. Alternately, $D$. discoideum undergoes a simple development cycle upon starvation, where a set of discrete proteins control aggregation and formation of a fruiting body, and this process can also be used to rapidly test compound effects and mutant resistance (Cocorocchio et al., 2018, Kelly et al., 2019). In addition, both the function and the cellular location of identified proteins can be characterised by generating $D$. discoideum mutant cell lines overexpressing the ablated gene or the orthologous human gene (Fischer et al., 2004, Ludtmann et al., 2014, Sekine et al., 2018). On a cellular level D. discoideum growth, movement and cell shape can also be used as a rapid readout system to analyse the effects of a compound (Cocorocchio et al., 2018, Robery et al., 2011, Robery etal., 2013). Thus, through identifying and analysing $D$. discoideum mutants lacking potential target proteins, the role of drugs or bioactive natural products can be rapidly explored at a cellular level.

\section{Pharmacological drug analysis and drug discovery}

Modern pharmaceutical drug development has tended to focus on the development of novel chemical structures, found through screening libraries of compounds or through iterative cycles of chemical modification and testing (Taylor, 2015). Resulting compounds are thus novel chemicals with efficacy against a known target or for regulating a disease-associated effect. Through this process, it is regularly assumed that the actions of the new drugs 
Fig. 2. The use of $\boldsymbol{D}$. discoideum in bipolar disorder and epilepsy research. A range of studies, originating in D. discoideum (b/ue) have investigated the cellular and molecular mechanisms of drugs used as bipolar disorder and epilepsy treatments, including valproic acid (VPA). Some of these studies have led to further research in both $\mathrm{D}$. discoideum and animal models (green) to validate drug mechanisms and to identify novel compounds with the potential of therapeutic tissue samples (yellow) have further validated these mechanisms and seizure control in pre-clinical models. Currently, this work has led to one clinical trial Igrey banner). Relevant papers are cited for each study. use. Further studies, in animal models or with human

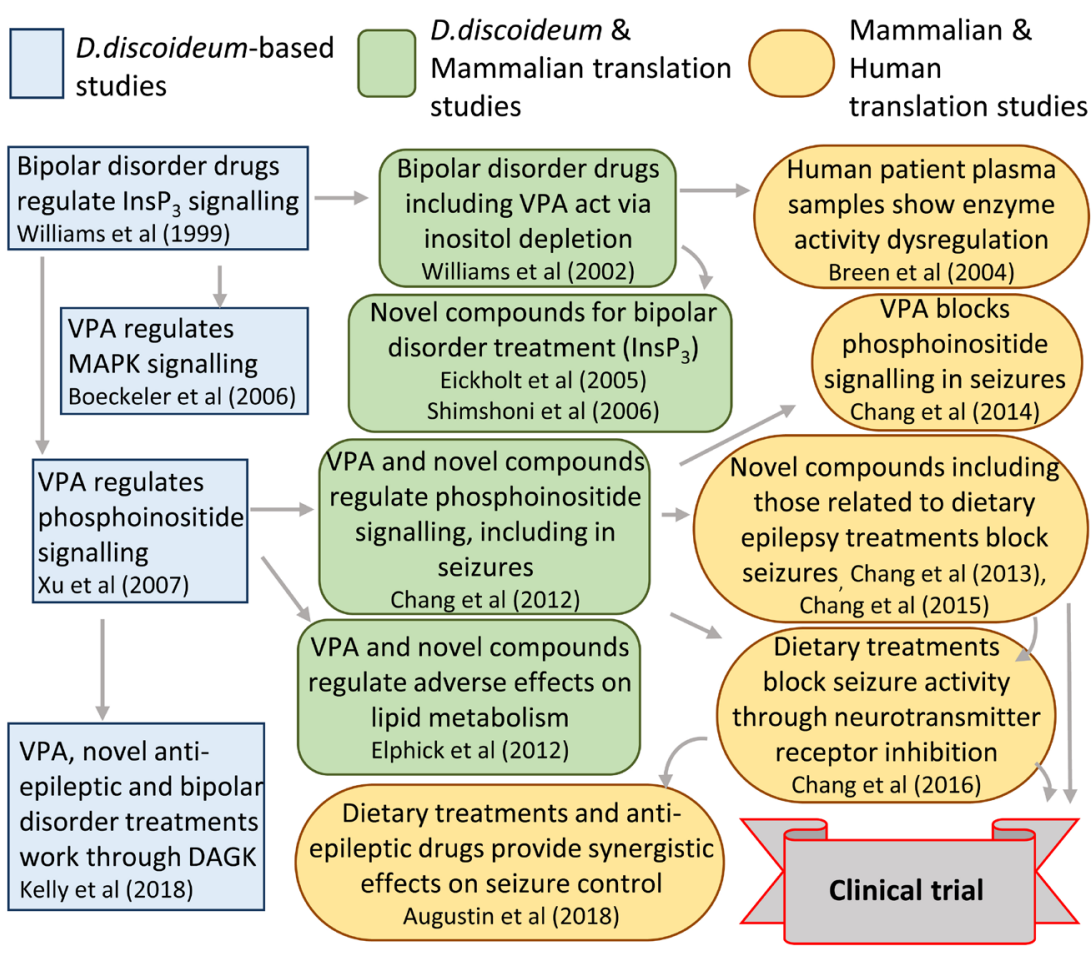

are very specific, and an understanding of potential secondary target effects often remain unknown. Surprisingly, in some cases and despite years of research, the primary drug targets is also unclear. The following sections describe the use of $D$. discoideum as a pharmacological model to study the molecular targets and mechanisms of known drugs and the use of this knowledge to identify potential novel drugs.

\section{Bipolar disorder research in a social amoeba}

$D$. discoideum has been used extensively as a model to investigate therapeutic mechanisms of bipolar disorder treatments. Bipolar disorder is a common neuropsychiatric condition characterised by dramatic changes in mood with potentially devastating impact on individuals and their quality of life, with incidence reports suggesting that $4.4 \%$ of the adult U.S. population experience this illness once in their lives (NIMH, 2017). Current treatment involves the life-long use of moodstabilizing drugs, where the mechanism of action of these treatments remains unclear. Some moodstabilizing drugs, such as lithium and valproic acid (VPA), have been suggested to inhibit glycogen synthase kinase 3 (GSK3) activity (Klein and Melton, 1996; Chen et al., 1999) or alternatively function through the depletion of inositol-containing compounds (the "inositol depletion theory") (Berridge et al., 1989).

The use of $D$. discoideum as a pharmacological model provided strong evidence that bipolar disorder treatments function through inositol depletion by reducing inositol phosphate signalling (Fig. 2) (Williams et al., 2002, Williams et al., 1999). To arrive at this conclusion, initial experiments were performed that showed that both lithium and VPA blocked the development cycle of $D$. discoideum, suggesting the presence of pharmacological targets in this model. Searching for these targets by screening a pool of insertional mutants, identified a lithium-resistant mutant with an inactivated gene encoding the enzyme prolyl oligopeptidase.
The encoded enzyme has been linked to patients with bipolar disorder (Breen et al., 2004, Williams, 2005). Further studies in $D$. discoideum showed that loss of prolyl oligopeptidase elevated inositol trisphosphate levels to overcome the reduction caused by lithium, thus linking a potential marker for bipolar disorder with a pharmacological mechanism of inositol depletion. This mechanism was then successfully translated to primary mammalian neurons, where lithium, VPA and a third bipolar disorder treatment (carbamazepine) commonly caused an enlargement of the neuronal growth cones, and this effect was reversed by co-treatment with inositol or by inhibiting the mammalian prolyl oligopeptidase (Williams et al., 2002). This discovery also enabled $D$. discoideum to be used to screen for novel chemicals related to VPA that retain this effect of inositol trisphosphate depletion, but were likely to lack serious side effects of VPA, providing a potential new treatment for bipolar disorder (Eickholt et al., 2005, Shimshoni et al., 2007).

Recent studies in $D$. discoideum have provided new mechanistic insight to VPA function linking both epilepsy and bipolar disorder treatment mechanism (Kelly etal., 2018) (Fig. 2). This study focused on the diacylglycerol kinase enzyme (DGKA) that functions in the phosphorylation of diacylglycerol (DAG) to produce phosphatidic acid in the phosphoinositide salvage pathway (Berridge, 2016), and thus is involved in inositol recycling. In $D$. discoideum, loss of this protein reduced the rapid changes caused by VPA on cell movement and on the inhibition of development caused by both VPA and lithium (Kelly et al., 2018). These outcomes suggested a key role for this protein as a regulator of bipolar disorder drugs at a cellular level. The study went on to employ a structure-activity relationship (SAR) approach, where the loss-of-function mutant was shown to be resistant to a range of potential treatments for epilepsy and bipolar disorder (Augustin et al., 2018a, Chang et al., 2012, Chang et al., 2013, Kelly et al., 2018), suggesting that these compounds may therefore function through the same pathway. In 
addition, several mammalian and human-based studies have linked DGKA function with epilepsy (Leach et al., 2007, Rodriguez de Turco et al., 2001) and bipolar disorder (Baum et al., 2007, Moya et al., 2010). Furthermore, DAG acts to regulate protein kinase $C$ (PKC) activity that is also elevated during manic episodes (Wang and Friedman, 1996), and lithium is known to increase DAG levels (Brami et al., 1993). Thus, the molecular mechanism of VPA may be evolutionarily conserved from $D$. discoideum to mammals, through DGKA-dependent signalling. These studies have therefore provided key insights into the molecular mechanism of VPA and have proposed DGKAas a new therapeutically-relevant drug target.

\section{Epilepsy research and new therapeutic approaches: from amoeba to humans}

The World Health Organization classifies VPA as an essential anti-epileptic medication (WHO, 2017), for the approximately 50 million people worldwide who experience epilepsy. VPA was serendipitously discovered to have anti-convulsant effects in 1963 (Terbach and Williams, 2009), and despite its efficacy and long-term use, its mechanism of action remains to be confirmed. Unfortunately, VPA has several severe side effects, such as hepatotoxicity, pancreatitis and teratogenicity that limit its use (Stadelmaier et al., 2017, Terbach and Williams, 2009). Thus, understanding its underlying molecular mechanisms may help to develop more effective and safer treatments.

$D$. discoideum has been widely used to explore potential anti-convulsant mechanisms of VPA to identify phosphoinositide signalling as a target (Fig. 2). Initial studies in D. discoideum, which focused on analysing VPA-induced biochemical changes that are related to epilepsy treatment, showed that VPA rapidly reduced directional cell movement (chemotaxis) by inhibiting phosphoinositide signalling (Chang et al., 2012, Xu et al., 2007). This observation led to the translation of this effect to mammalian models, where radioactively-labelled inositol was used to monitor phosphoinositides in primary rat neurons, and seizure-like activity was induced, followed by VPA treatment. From this study, seizure activity was found to reduce phosphatidylinositol trisphosphate $\left(\mathrm{PIP}_{3}\right)$, and this effect was blocked by VPA (Chang et al., 2014). This effect was verified using ex vivo and in vivo seizure models, providing strong evidence for this mechanism in the brain.

The VPA-dependent effect of phosphoinositide signalling in $D$. discoideum was also used leading to the identification of potential new anti-epileptic drugs (Chang et al., 2012). Here, more than 100 novel compounds were analysed for inhibitory effects on phosphoinositide signalling to identify novel structures showing increased potency over VPA. From this screen, a new family of active compounds were identified containing branched chain derivatives of medium-chain fatty acids with an eight (octanoic acid) or nine carbon (nonanoic acid) backbone. Several of these compounds were then shown to be effective in seizure control in both in vitro and in vivo mammalian models (Chang et al., 2016, Chang et al., 2012, Chang et al., 2013, Chang et al., 2015), and as neuroprotective agents (Chang et al., 2015), validating this mechanism of drug discovery. Related compounds are still being developed for ultimate assessment in clinical trials.

Another compound identified in the $D$. discoideum-based antiepileptic drug screen was decanoic acid (Chang et al., 2012) (Fig. 2), a key component of a therapeutic diet used to treat patients with drug resistant epilepsy (Augustin et al., 2018a, Neal et al.,
2009). Dietary treatments for epilepsy are important, since approximately $30 \%$ of patients are resistant to anti-epileptic drugs, and specialised diets remain a key approach to treat these individuals (D'Andrea Meira et al., 2019). These diets, commonly called 'ketogenic' diets, involve a low carbohydrate and protein intake, supplemented by long chain fatty acids (in a classical ketogenic diet) or medium-chain fatty acids (in a medium-chain triglyceride (MCT) ketogenic diet) (Augustin et al., 2018a, D'Andrea Meira et al., 2019, Warren et al., 2018). These diets have traditionally been thought to function through the breakdown of fatty acids to produce chemicals called ketones that were thought to be the therapeutically active agents, although evidence for this mechanism remains limited (Augustin et al., 2018a). The identification of decanoic acid in the $D$. discoideum anti-epileptic screen suggested that this medium-chain fatty acid may provide direct seizure control independent of its breakdown to ketones (Chang et al., 2012). This was subsequently validated in multiple in vitro seizure models (Chang et al., 2016, Chang et al., 2012, Chang et al., 2013, Chang et al., 2015). Subsequent experiments in mammalian models have shown that decanoic acid directly inhibits a key neurotransmitter receptor and thereby suppresses excitatory neurotransmission (Chang et al., 2016) involved in seizure activity (Augustin et al., 2018a, Augustin et al., 2018b, Chang et al., 2016). Since this mechanism is also shared by the pharmaceutical epilepsy treatment perampanel (Patsalos, 2015), further studies showed a synergistic effect of decanoic acid and perampanel on neurotransmission receptor function and seizure control (Augustin et al., 2018b). Finally, a diet that is rich in decanoic acid has anticonvulsant effects in an in vivo seizure model (Tan et al., 2016), independent of ketone generation, supporting a distinct role for decanoic acid (rather than ketones) in seizure control. All these studies provide evidence that some medium-chain fatty acids, including decanoic acid, have anti-convulsant properties. The observations made in $D$. discoideum and in mammalian seizure models have been used to develop a novel MCT-based diet and a clinical trial to test the efficiency of this diet in epileptic patients is currently ongoing (Augustin et al., 2018a).

Other studies in $D$. discoideum have also shown that VPA elevates the activity of the mitogen-activated protein kinase (MAPK) signalling pathway (Boeckeler et al., 2006), consistent with observations made in mammalian studies (Hao et al., 2004). This mechanism may explain the neuroprotective effects of VPA. In addition to analysing positive therapeutic effects of VPA, D. discoideum has also been used to assess adverse effects of VPA and related analogues, including teratogenicity and hepatotoxicity (Eickholt et al., 2005, Elphick et al., 2012).

\section{Treating cancer: lessons from $D$. discoideum}

In 2018, cancer was responsible for approximately 9.6 million deaths worldwide, which makes it the second leading cause of death (WHO, 2018). One of the most common treatments for cancer are chemotherapeutic drugs, such as the platinum-based drug cisplatin (Kelland, 2007). As a cancer treatment, the antiproliferative effects of cisplatin were accidentally discovered in 1965 and currently platinum-based drugs are used for the treatment of various solid tumours, in particular testicular or ovarian cancer, where it is assumed that they cause cytotoxicity mainly by covalently binding to DNA molecules (Kelland, 2007). Despite their wide use, cisplatin and related drugs have severe side ef- 
fects and patients often become drug resistant. Thus, an improved understanding of the mechanism through which cisplatin functions may help to overcome these adverse effects.

$D$. discoideum has been used to study the molecular mechanisms underlying cisplatin treatment. Studies into this mechanism initially employed a library of $D$. discoideum mutants that were screened for cells showing resistance to the effect of cisplatin. One cisplatin resistant mutant showed loss of sphingosine-1-phosphate (S-1-P) lyase activity (Li et al., 2000). Based on this, it was shown that sensitivity to cisplatin was regulated by the balance between the two lipids, ceramide and S-1-P (Alexander and Alexander, 2011). In these experiments, increasing the ratio of S-1-P to ceramide through ablation of the S-1-P lyase or through overexpression of the sphingosine kinase decreased the sensitivity of $D$. discoideum cells to cisplatin ( $\mathrm{Li}$ et al., 2000, Min et al., 2005a). In contrast, increasing the ratio of ceramide to $\mathrm{S}-1-\mathrm{P}$ by overexpressing the S-1-P lyase or by ablating the sphingosine kinase, increased the sensitivity of $D$. discoideum cells to cisplatin (Min et al., 2004, Min et al., 2005a). Thus, these studies proposed a novel mechanism of action for cisplatin as an anti-cancer agent. The pivotal role of sphingolipid metabolism in controlling sensitivity to cisplatin was confirmed in human-derived cell lines by overexpression of sphingolipid metabolism genes, including S-1-P lyase, ceramide synthase 1 and sphingosine kinase 1 (Min et al., 2007, Min et al., 2005b). Overexpression of S-1-P lyase was confirmed in HEK293 or A549 cells to have the same phenotype as in D. discoideum increased sensitivity to cisplatin (Min et al., 2005b). Overexpressing sphingosine kinase 1 in HEK293 cells decreased cisplatin sensitivity, whereas overexpression of sphingosine kinase 2 has the opposite effect (Min etal., 2007). Similarly, overexpressing ceramide synthase 1 , but not ceramide synthase 4 and 5 , in cell lines enhanced the sensitivity of cells to cisplatin. These data provide important new insights in the cellular mechanisms regulating cisplatin sensitivity.

$D$. discoideum has also been used in a range of other cancerrelated studies. The role of cisplatin on gene expression in the model has been analysed (Van Driessche et al., 2007), in addition to its regulation of mitogen activated protein kinase phosphatases (Moncho-Amor et al., 2011) and in DNA repair pathways (Gunn et al., 2016). The cellular functions of other anti-cancer treatments, such as bestatin and Poly (ADPribose) polymerase inhibitors have also been analysed in D. discoideum (Kolb et al., 2017, Poloz et al., 2012). Finally, Dictyostelium strains have also been shown to provide a source of novel compounds with anti-proliferative properties that could thus be used as cancer treatments (Honma et al., 2018, Kubohara and Kikuchi, 2018).

\section{Investigating novel anti-microbial drugs using D. discoideum}

The discovery of novel anti-microbial compounds for the treatment of infectious diseases is very important. In 2010, approximately 15 million people worldwide died from infectious diseases and infection provides the leading cause of death in low income countries (Dye, 2014), therefore efficient approaches to develop novel antibiotics are needed.

$D$. discoideum has been proposed as a novel model host for virulent bacteria, enabling the identification of compounds with antimicrobial properties. In one series of studies, $D$. discoideum cells grown on lawns comprising a single bacterial species (Klebsiella pneumoniae) as the food source form plaques and subsequently aggregate and develop into fruiting bodies. In contrast, plaque formation and development is impeded by the presence of the virulent strain Mycobacterium marinum (a model organism to study tuberculosis infections) or the pathogenic strain Pseodomonas aeruginosa PAO1 (Bravo-Toncio et al., 2016, Ouertatani-Sakouhi et al., 2017). Mechanistic insight into this effect was shown when $D$. discoideum was able to form plaques and aggregate in the presence of a $P$. aeruginosa mutant which lacks the polyphosphate kinase 1 (PPK1). Based on this observation, D. discoideum was employed as a host to conduct a screen with thirty compounds that could inhibit the $P$. aeruginosa PPK1 and therefore might have anti-microbial properties (Bravo-Toncio et al., 2016). In a similar manner, a high-throughput screen was performed with a large array of compounds to identify those that allow plaque formation of $D$. discoideum in the presence of $M$. marinum, through either directly inhibiting mycobacterial growth or decreasing Mycobacteria virulence (Ouertatani-Sakouhi et al., 2017). These $D$. discoideum-based screens, and others that exploited $D$. discoideum in secondary assays to further characterise the function of compounds (Trofimov et al., 2018; Kicka et al., 2014; Harrison et al., 2015; Slepikas et al., 2016), highlight the value of $D$. discoideum as a host model to quickly screen a large number of potential anti-microbial compounds.

Similarly, D. discoideum along with macrophages and Acanthamoeba castellanii were also used to investigate the effectiveness of a potential anti-Legionella pneumophila drug (Harrison et al., 2015). This study successfully demonstrated that an amoeba can be employed to find novel inhibitors of $L$. phneumophila intracellular replication (Harrison et al., 2015). D. discoideum was then further used to determine which mutants of L. phneomophila had replication defects (Harrison et al., 2013). Thus, $D$. discoideum provides a successful model for virulent bacterial infection and the discovery of new anti-bacterial drugs.

Intriguingly, $D$. discoideum also represents a novel source of anti-microbial compounds. For instance, it has been shown that the $D$. discoideum protein ApID (amoebaporelike protein D) has anti-microbial effects by destroying the integrity of bacterial membranes (Dhakshinamoorthy et al., 2018). In addition, further $D$. discoideum-based screening assays have been developed to screen for compounds that restore the function of impaired versions of the human phenylalanine hydroxylase enzyme (Kim et al., 2015) or for compounds that inhibit chemotaxis of immune or cancer cells (Liao et al., 2016).

\section{Natural product medicines - learning from nature?}

Natural compounds have been used for centuries as medicinal remedies (Taylor, 2015). For many of these remedies, detailed analysis has validated the potential therapeutic efficacies of specifically purified components, although how these compounds work at a molecular or cellular level often remains unclear, making ultimate validation significantly more difficult. Thus, using a tractable biological system such as $D$. discoideum can help to define the molecular and cellular effects of natural compounds, enabling the validation of these mechanisms in mammalian models (MullerTaubenberger et al., 2013, Warren et al., 2018, Williams et al., 2006). The following sections describe the use of $D$. discoideum as a pharmacological model to study the molecular targets and mechanisms of action of bioactive natural products associated with traditional remedies (Fig. 3). 


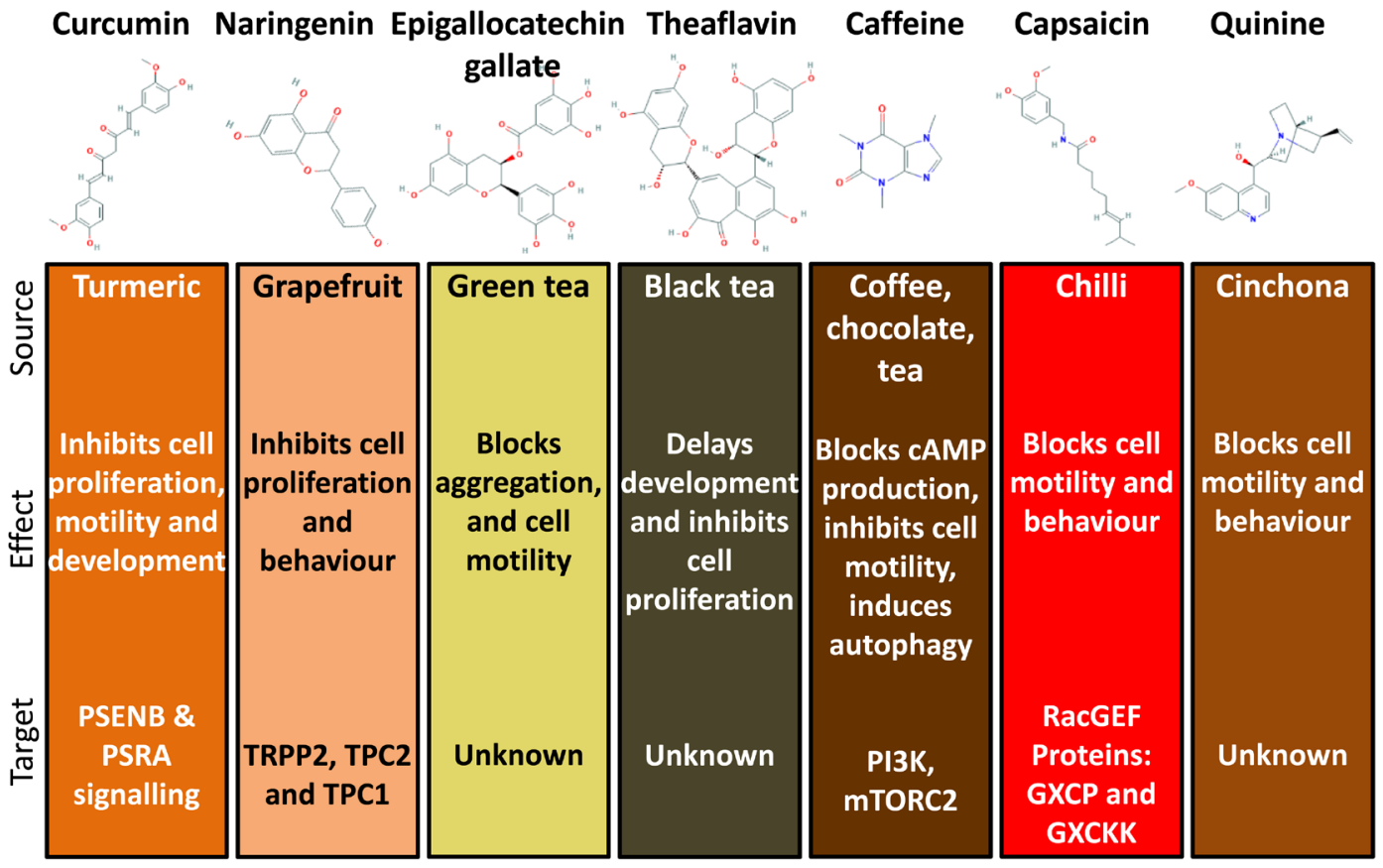

Fig. 3. Naturally occurring bioactive compounds have been investigated using $\boldsymbol{D}$. discoideum. A range of studies in $\mathrm{D}$. discoideum have focused on natural products that have suggested to have positive effects on health or in disease treatment. These compounds have complex and varied chemical structures, and they are derived from a wide-ranging plants. Analysis of each compound using D. discoideum has shown effects on cell proliferation, cell motility or behaviour, and development. In several cases, molecular targets or pathways have been proposed. PSENB, presenilin B protein; psrA, serine/threonine-protein phosphatase $2 A$ regulatory subunit; TPC1/2, two-pore channel 1/2; TRPP2, transient receptor potential cation channel; PI3K, phosphatidylinositol 3-kinase; mTORC2, mechanistic target of rapamycin complex 2; RacGEF, Rho family GTPase guanine nucleotide exchange factor.

\section{The golden spice - medical insights from Turmeric-derived Curcumin}

One naturally occurring bioactive compound that has been characterised using $D$. discoideum is the polyphenol curcumin, derived from the spice turmeric (Fig. 3). Turmeric has been used as a treatment for inflammatory disorders for centuries, and curcumin has been proposed as a treatment for many diseases such as heart disease, cancer, inflammatory disorders, allergies, Alzheimer's disease and asthma (Hewlings and Kalman, 2017).

In both $D$. discoideum (Cocorocchio et al., 2018, Garige and Walters, 2015, Swatson et al., 2017) and mammalian systems (Kunnumakkara et al., 2008), curcumin inhibits cellular growth, allowing $D$. discoideum to be used to explore the molecular mechanisms behind this effect. Curcumin delays the chemotatic response towards cyclic AMP (cAMP), blocks the formation of fruiting bodies during starvation, and reduces the expression of genes essential for development (Cocorocchio et al., 2018, Garige and Walters, 2015). To determine which key features of the curcumin molecule were responsible for these effects, multiple curcumin derivatives were tested in a quantitative structure-activity relationship (QSAR) study (Cocorocchio et al., 2018). From this study, specific regions of the chemical structure (e.g. the diketone group and the $\alpha, \beta$-unsaturated carbonyl moiety on the sevencarbon linker) were demonstrated to be essential for the effects on acute cell behaviour. To investigate molecular targets for this compound, a genetic screen was also employed to isolate mutants resistant to curcumin during growth. This approach identified that the protein phosphatase $2 \mathrm{~A}(\mathrm{PP} 2 \mathrm{~A})$ regulatory subunit (psrA) and the presenilin $B$ protein controlled sensitivity to both curcumin and specific analogues during growth. These targets potentially link the use of curcumin with treatments for cancer (Kiely and Kiely, 2015) and Alzheimer's disease (Ludtmann et al., 2014, Sharma et al., 2019), and further translational studies are necessary to continue this research. Another study has also shown that protein kinase $A(P K A)$ contributes to mediating the effects of curcumin on cell proliferation and transcriptional regulation (Swatson et al., 2017). Interestingly, these $D$. discoideum studies suggest that the cellular mechanisms of curcumin are not solely, as assumed by other studies (Hewlings and Kalman, 2017), based on its anti-oxidant and anti-inflammatory properties, but that curcumin instead functions through specific cell signalling mechanisms and transcription effects. Thus, further insights into the cellular and molecular effects of curcumin may indeed lead to the discovery of molecular targets and mechanisms of action for curcumin in health and medicine.

\section{Finding the function of flavonoids}

Flavonoids represent a large group of compounds that are often associated with positive health effects and potential medicinal benefits (Panche et al., 2016). Although most of these compounds are thought to function through anti-oxidative and anti-inflammatory roles, many flavonoids have also been implicated in the modulation of key cell signalling functions, and identifying and characterising these targets and mechanisms should help to validate their therapeutic potential.

$D$. discoideum has been used to investigate the flavonoid naringenin (Fig. 3), a polyphenol compound found in grapefruit, which has been associated with a wide range of health and medical 
benefits (Salehi etal., 2019). In D. discoideum, naringenin reduces cell growth, blocks cellular movement and causes cells to lose shape following acute (30 min) exposure (Waheed et al., 2014). Employing this growth effect, a $D$. discoideum mutant library was screened to identify naringenin resistant-cells including mutants lacking the transient receptor potential cation channel (TRPP2), which is encoded by the polycystic kidney disease 2 (PKD2) gene (Waheed et al., 2014), suggesting that this protein may be a direct target of naringenin. To validate this target, the effects of the flavonoid on $D$. discoideum cell movement and cell shape were assessed in cells lacking TRPP2, thus confirming a role for TRPP2 in the cellular function of naringenin in this model. Excitingly, mutations in the human TRPP2 orthologue are associated with polycystic kidney disease where patients develop debilitating kidney cysts, suggesting that naringenin may provide a treatment for this disorder. To examine this, a canine kidney cell line (Madin-Darby Canine Kidney - MDCK cells) was induced to form cysts, and naringenin was shown to block cyst formation through a TRPP2-dependent mechanism (Waheed et al., 2014). These data suggest a conserved function of the $D$. discoideumand canine TRPP2 proteins as a target for naringenin. In a subsequent study exploring the effect of naringenin on proteins related to TRPP2, naringenin impaired the activity of the human two-pore channel 1 (TPC1) and two-pore channel 2 (TPC2) proteins (Pafumi et al., 2017). Thus, the discovery that growth inhibitory effects of naringenin in $D$. discoideum are controlled by TRPP2 has identified a specific molecular target of naringenin in mammalian cells with potential therapeutic implications relating to the treatment of polycystic kidney disease.

Two $D$. discoideum studies have examined other flavonoids contained in different forms of tea, such as epigallocatechin gallate (EGCG) and theaflavins. Surprisingly little is known regarding the cellular and molecular mechanisms of these flavonoids. EGCG is one of the most abundant catechins in green tea $(59 \%$ of total catechin) (Leung et al., 2001), and has potential health benefits in cancer treatments, autoimmune regulation and metabolic disease therapy (Legeay et al., 2015, Rawangkan et al., 2018). Theaflavins are found predominantly in black tea (Leung et al., 2001) and are thought to have neuroprotective, anti-inflammatory (Anandhan et al., 2013) and anti-hyperlipidaemia effects (Imran et al., 2018). In D. discoideum (Fig. 3), ECGC inhibits random cell movement and directional movement (chemotaxis), blocking aggregation and stalling development at a loose mound stage (McQuade et al., 2013). Theaflavins also blocked $D$. discoideumgrowth, and delayed multicellular development by 5 hours in addition to reducing the formation of fruiting bodies (Ilacqua et al., 2017). Although both these studies did not propose cellular targets for the flavonoids, they establish cellular effects for the compounds and suggest molecular targets for both compounds are present in the model.

\section{What is coffee to an amoeba?}

Caffeine is a purine alkaloid that is naturally occurring in coffee, tea and chocolate and is one of the most frequently ingested neuroactive compounds in humans (Saiki et al., 2011, Temple et al., 2017). One mechanism of caffeine is through the non-competitive antagonism of adenosine receptors (Fredholm et al., 1999). In $D$. discoideum (Fig. 3), caffeine blocks activation of cAMP synthesis through blocking adenylyl cyclase activity (Theibert and Devreotes, 1983), thereby preventing the extracellular chemoattractant role of
CAMP in addition to its role as an intracellular second messenger (Reymond et al., 1995). A more recent study in $D$. discoideum shows an effect of caffeine through inhibiting pathways downstream of cAMP signalling, including the phosphatidylinositol 3-kinase (PI3K), mTOR Complex 2 (mTORC2), and protein kinase A(PKA) signalling pathways, as well as the extracellular signal-regulated kinases 1/2 (ERK1 and ERK2) (Tariqul Islam et al., 2019). The caffeine-dependent inhibition of the PI3K/mTORC2 pathway has also been demonstrated in mammalian models, where it has been associated with induction of autophagy (Saiki et al., 2011). Finally, in both $D$. discoideumand mammalian neutrophils, caffeine inhibits chemotaxis (Elferink and De Koster, 1995) as well as the migration of tumour cells in the human gut, through antagonising adenosine receptors (Merighi et al., 2007). Therefore, studies of caffeine in $D$. discoideum complement and extend those in mammalian models.

\section{A broad selection of natural products modify $D$. discoideum behaviour}

$D$. discoideum has been employed in many other studies to assess the effects of natural compounds. For example, one study employed $D$. discoideum as a model organism to quantify the taste quality of bitterness for a range of natural products and drugs. In these studies, $D$. discoideum cell motility was shown to be strongly inhibited by pungent and bitter tastants, such as capsaicin, a constituent of chilli, and quinine hydrochloride; quinine naturally occurs in the cinchona tree and is used as an antimalarial drug (Achan et al., 2011) (Fig. 3) (Cocorocchio et al., 2016, Otto et al., 2016, Robery et al., 2011, Robery et al., 2013). Within these studies, a strong correlation was found between the effects of bitter tastants on $D$. discoideum cell motility and effects in rat and human taste studies, where compounds that were found most potent in $D$. discoideum cell movement assays were also the strongest bitter tastant in rats and humans (Cocorocchio et al., 2016). This provides the possibility of using $D$. discoideum as an early model for testing compounds for their level of bitterness and whether they have a strong bitter taste before they are developed into human drugs (Williams and Andrews, 2019).

\section{Summary}

Improving our understanding of the molecular and cellular actions of therapeutic drugs and bioactive natural products will significantly aid the development of more effective and safer medicinal treatments. Identifying the mechanisms of action and direct targets of medicinal compounds in mammalian model systems can be difficult, unless potential targets and mechanisms can be proposed for focused analysis. In recent years, many studies have demonstrated that $D$. discoideum provides a valuable biomedical model for the study of known drugs and bioactive natural products, as well as in the discovery of novel compounds with medicinal effects. These advances have been possible, since $D$. discoideum offers a range of advantageous research techniques, including genetic screening, rapid targeted gene ablation, and assays for acute cell behaviour and chronic developmental effects that can be used as readouts. Numerous $D$. discoideum-based studies indicate that if a therapeutic drug or natural product has an effect on $D$. discoideum at concentrations related to physiological use, the model provides an excellent platform for identifying potential target proteins and mechanisms of action for these compounds. 


\section{Acknowledgement}

JS is funded by a Department of Biological Science PhD studentship award.

\section{References}

ACHAN, J., TALISUNA, A.O., ERHART, A., YEKA, A., TIBENDERANA, J.K., BALIRAINE, F.N., ROSENTHAL, P.J. and D'ALESSANDRO, U. (2011). Quinine, an old anti-malarial drug in a modern world: role in the treatment of malaria. Malar J 10: 144.

ALEXANDER, S. and ALEXANDER, H. (2011). Lead genetic studies in Dictyostelium discoideum and translational studies in human cells demonstrate that sphingolipids are key regulators of sensitivity to cisplatin and other anticancer drugs. Semin Cell Dev Biol 22: 97-104.

ANANDHAN, A., ESSA, M.M. and MANIVASAGAM, T. (2013). Therapeutic attenuation of neuroinflammation and apoptosis by black tea theaflavin in chronic MPTP/ probenecid model of Parkinson's disease. Neurotox Res 23: 166-173.

AUGUSTIN, K., KHABBUSH, A., WILLIAMS, S., EATON, S., ORFORD, M., CROSS, J.H., HEALES, S.J.R., WALKER, M.C. and WILLIAMS, R.S.B. (2018a). Mechanisms of action for the medium-chain triglyceride ketogenic diet in neurological and metabolic disorders. Lancet Neurol 17: 84-93.

AUGUSTIN, K., WILLIAMS, S., CUNNINGHAM, M., DEVLIN, A.M., FRIEDRICH, M., JAYASEKERA, A., HUSSAIN, M.A., HOLLIMAN, D., MITCHELL, P., JENKINS, A. et al., (2018b). Perampanel and decanoic acid show synergistic action against AMPA receptors and seizures. Epilepsia 59: e172-e178.

BAUM, A.E., AKULA, N., CABANERO, M., CARDONA, I., CORONA, W., KLEMENS, B., SCHULZE, T.G., CICHON, S., RIETSCHEL, M., NOTHEN, M.M. et al., (2007). A genome-wide association study implicates diacylglycerol kinase eta (DGKH) and several other genes in the etiology of bipolar disorder. Mol. Psychiatry 13: 10.

BERRIDGE, M.J. (2016). The Inositol Trisphosphate/Calcium Signaling Pathway in Health and Disease. Physiol Rev 96: 1261-1296.

BERRIDGE, M.J., DOWNES, C.P. and HANLEY, M.R. (1989). Neural and developmental actions of lithium: a unifying hypothesis. Cell 59: 411-419.

BRAMI, B.A., LELI, U. and HAUSER, G. (1993). Elevated phosphatidyl-CMP is not the source of diacylglycerol accumulation induced by lithium in NG108-15 cells. J Neurochem 60: 1137-1142.

BRAVO-TONCIO, C., ALVAREZ, J.A., CAMPOS, F., ORTIZ-SEVERIN, J., VARAS, M., CABRERA, R., LAGOS, C.F. and CHAVEZ, F.P. (2016). Dictyostelium discoideum as a surrogate host-microbe model for antivirulence screening in Pseudomonas aeruginosa PAO1. Int J Antimicrob Agents 47: 403-409.

BREEN, G., HARWOOD, A.J., GREGORY, K., SINCLAIR, M., COLLIER, D., ST CLAIR, D. and WILLIAMS, R.S. (2004). Two peptidase activities decrease in treated bipolar disorder not schizophrenic patients. Bipolar Disord 6: 156-161.

CHANG, P., AUGUSTIN, K., BODDUM, K., WILLIAMS, S., SUN, M., TERSCHAK, J.A., HARDEGE, J.D., CHEN, P.E., WALKER, M.C. and WILLIAMS, R.S. (2016). Seizure control by decanoic acid through direct AMPA receptor inhibition. Brain 139: 431-443

CHANG, P., ORABI, B., DERANIEH, R.M., DHAM, M., HOELLER, O., SHIMSHONI, J.A., YAGEN, B., BIALER, M., GREENBERG, M.L., WALKER, M.C. et al., (2012). The antiepileptic drug valproic acid and other medium-chain fatty acids acutely reduce phosphoinositide levels independently of inositol in Dictyostelium. Dis. Model. Mech 5: 115-124.

CHANG, P., TERBACH, N., PLANT, N., CHEN, P.E., WALKER, M.C. and WILLIAMS, R.S. (2013). Seizure control by ketogenic diet-associated medium chain fatty acids. Neuropharmacology 69: 105-114.

CHANG, P., WALKER, M.C. and WILLIAMS, R.S. (2014). Seizure-induced reduction in PIP3 levels contributes to seizure-activity and is rescued by valproic acid. Neurobiol. Dis 62: 296-306.

CHANG, P., ZUCKERMANN, A.M., WILLIAMS, S., CLOSE, A.J., CANO-JAIMEZ, M., MCEVOY, J.P., SPENCER, J., WALKER, M.C. and WILLIAMS, R.S. (2015). Seizure control by derivatives of medium chain fatty acids associated with the ketogenic diet show novel branching-point structure for enhanced potency. $J$. Pharmacol. Exp. Ther 352: 43-52.

CHEN G, HUANG LD, JIANG YM, and MANJI HK. (1999). The moodstabilizing agent valproate inhibits the activity of glycogen synthase kinase-3. J Neurochem 72 : 1327-1330.
COCOROCCHIO, M., BALDWIN, A.J., STEWART, B., KIM, L., HARWOOD, A.J., THOMPSON, C.R.L., ANDREWS, P.L.R. and WILLIAMS, R.S.B. (2018). Curcumin and derivatives function through protein phosphatase $2 \mathrm{~A}$ and presenilin orthologues in Dictyostelium discoideum. Dis Model Mech 11: 10.

COCOROCCHIO, M., IVES, R., CLAPHAM, D., ANDREWS, P.L. and WILLIAMS, R.S. (2016). Bitter tastant responses in the amoeba Dictyostelium correlate with rat and human taste assays. ALTEX 33: 11.

D'ANDREA MEIRA, I., ROMAO, T.T., PIRES DO PRADO, H.J., KRUGER, L.T., PIRES, M.E.P. and DA CONCEICAO, P.O. (2019). Ketogenic Diet and Epilepsy: What We Know So Far. Front Neurosci 13: 5

DHAKSHINAMOORTHY, R., BITZHENNER, M., COSSON, P., SOLDATI, T. and LEIPPE, M. (2018). The Saposin-Like Protein ApID Displays Pore-Forming Activity and Participates in Defense Against Bacterial Infection During a Multicellular Stage of Dictyostelium discoideum. Front Cell Infect Microbiol 8: 73.

DYE, C. (2014). After 2015: infectious diseases in a new era of health and development. Philos Trans R Soc Lond B Biol Sci 369: 20130426.

EICHINGER, L., PACHEBAT, J.A., GLOCKNER, G., RAJANDREAM, M.A., SUCGANG R., BERRIMAN, M., SONG, J., OLSEN, R., SZAFRANSKI, K., XU, Q. etal., (2005). The genome of the social amoeba Dictyostelium discoideum. Nature 435: 43-57.

EICKHOLT, B.J., TOWERS, G., RYVES, W.J., EIKEL, D., ADLEY, K., YLINEN, L., CHADBORN, N., HARWOOD, A., NAU, H. and WILLIAMS, R.S. (2005). Effects of valproic acid derivatives on inositol trisphosphate depletion, teratogenicity, GSK-3b inhibition and viral replication - A screening approach for new bipolar disorder drugs based on the valproic acid core structure. Mol. Pharmacol 67: 7 .

ELFERINK, J.G. and DE KOSTER, B.M. (1995). Ryanodine as inhibitor of chemotactic peptide-induced chemotaxis in human neutrophils. Biochem Pharmacol 50: 975-979.

ELPHICK, L.M., PAWOLLECK, N., GUSCHINA, I.A., CHAIEB, L., EIKEL, D., NAU, H., HARWOOD, J.L., PLANT, N.J. and WILLIAMS, R.S. (2012). Conserved valproicacid-induced lipid droplet formation in Dictyostelium and human hepatocytes identifies structurally active compounds. Dis. Model. Mech 5: 231-240.

FISCHER, M., HAASE, I., SIMMETH, E., GERISCH, G. and MULLER-TAUBENBERGER, A. (2004). A brilliant monomeric red fluorescent protein to visualize cytoskeleton dynamics in Dictyostelium. FEBS Lett 577: 227-232.

FREDHOLM, B.B., BATTIG, K., HOLMEN, J., NEHLIG, A. and ZVARTAU, E.E. (1999). Actions of caffeine in the brain with special reference to factors that contribute to its widespread use. Pharmacol Rev 51: 83-133.

GAITATZIS, A. and SANDER, J.W. (2013). The long-term safety of antiepileptic drugs CNS Drugs 27: 435-55.

GARIGE, M. and WALTERS, E. (2015). Curcumin inhibits development and cell adhesion in Dictyostelium discoideum: Implications for YakA signaling and GST enzyme function. Biochem Biophys Res Commun 467: 275-281.

GUNN, A.R., BANOS-PINERO, B., PASCHKE, P., SANCHEZ-PULIDO, L., ARIZA, A., DAY, J., EMRICH, M., LEYS, D., PONTING, C.P., AHEL, I. et al., (2016). The role of ADP-ribosylation in regulating DNA interstrand crosslink repair. J Cell Sci 129: 3845-3858.

HAO, Y., CRESON, T., ZHANG, L., LI, P., DU, F., YUAN, P., GOULD, T.D., MANJI, H.K. and CHEN, G. (2004). Mood stabilizer valproate promotes ERK pathwaydependent cortical neuronal growth and neurogenesis. J. Neurosci24:6590-6599.

HARRISON, C.F., CHIRIANO, G., FINSEL, I., MANSKE, C., HOFFMANN, C., STEINER, B., KRANJC, A., PATTHEY-VUADENS, O., KICKA, S., TROFIMOV, V. et al., (2015). Amoebae-Based Screening Reveals a Novel Family of Compounds Restricting Intracellular Legionella pneumophila. ACS Infect Dis 1: 327-338.

HARRISON, C.F., KICKA, S., TROFIMOV, V., BERSCHL, K., OUERTATANI-SAKOUHI, H., ACKERMANN, N., HEDBERG, C., COSSON, P., SOLDATI, T. and HILBI, H. (2013). Exploring anti-bacterial compounds against intracellular Legionella. PLoS One 8: e74813.

HEWLINGS, S.J. and KALMAN, D.S. (2017). Curcumin: A Review of Its' Effects on Human Health. Foods 6(10), 92.

HONMA, S., KOUNO, K., TAKASAKA, S., MITAZAKI, S., ABE, S., KIKUCHI, H., OSHIMA, Y. and YOSHIDA, M. (2018). Effect of brefelamide on proliferation of $1321 \mathrm{~N} 1$ human astrocytoma cells induced by glial cell line-derived neurotrophic factor. Pharmazie 73: 22-28.

ILACQUA, A.N., SHETTLER, J.A., WERNKE, K.M., SKALLA, J.K. and MCQUADE, K.J. (2017). Theaflavins from black tea affect growth, development, and motility in Dictyostelium discoideum. Biochem Biophys Res Commun 491: 449-454. 
IMRAN, A., BUTT, M.S., ARSHAD, M.S., ARSHAD, M.U., SAEED, F., SOHAIB, M. and MUNIR, R. (2018). Exploring the potential of black tea based flavonoids against hyperlipidemia related disorders. Lipids Health Dis 17: 57.

KELLAND, L. (2007). The resurgence of platinum-based cancer chemotherapy. Nat Rev Cancer 7: 573-584.

KELLY, E., SHARMA, D., WILKINSON, C.J. and WILLIAMS, R.S.B. (2018). Diacylglycerol kinase (DGKA) regulates the effect of the epilepsy and bipolar disorder treatment valproic acid in Dictyostelium discoideum. Dis Model Mech 11 (9).

KICKA, S., TROFIMOV, V., HARRISON, C., OUERTATANI-SAKOUHI, H., MCKINNEY, J., SCAPOZZA, L., HILBI, H., COSSON, P. and SOLDATI, T. (2014). Establishment and validation of whole-cell based fluorescence assays to identify antimycobacterial compounds using the Acanthamoeba castellanii-Mycobacterium marinum host-pathogen system. PLoS One 9: e87834.

KIELY, M. and KIELY, P.A. (2015). PP2A: The Wolf in Sheep's Clothing? Cancers (Basel) 7: 648-669.

KIM, Y.M., YANG, Y.G., KIM, H.L. and PARK, Y.S. (2015). Dictyostelium discoideum Ax2 as an Assay System for Screening of Pharmacological Chaperones for Phenylketonuria Mutations. J Microbiol Biotechnol 25: 782-787.

KLEIN, P.S. and MELTON, D.A. (1996). A molecular mechanism for the effect of lithium on development. Proc. Natl. Acad. Sci. USA 93: 8455-8459.

KOLB, A.L., GUNN, A.R. and LAKIN, N.D. (2017). Redundancy between nucleases required for homologous recombination promotes PARP inhibitor resistance in the eukaryotic model organism Dictyostelium. Nucleic Acids Res 45: 10056-10067.

KUBOHARA, Y. and KIKUCHI, H. (2018). Dictyostelium: An Important Source of Structural and Functional Diversity in Drug Discovery. Cells 8 (1).

KUNNUMAKKARA, A.B., ANAND, P. and AGGARWAL, B.B. (2008). Curcumin inhibits proliferation, invasion, angiogenesis and metastasis of different cancers through interaction with multiple cell signaling proteins. Cancer Lett 269: 199-225.

LAUGSAND, E.A., JAKOBSEN, G., KAASA, S. and KLEPSTAD, P. (2011). Inadequate symptom control in advanced cancer patients across Europe. Support Care Cancer 19: 2005-2014.

LEACH, N.T., SUN, Y., MICHAUD, S., ZHENG, Y., LIGON, K.L., LIGON, A.H., SANDER, T., KORF, B.R., LU, W., HARRIS, D.J. et al., (2007). Disruption of diacylglycerol kinase delta (DGKD) associated with seizures in humans and mice. Am J Hum Genet 80: 792-799.

LEGEAY, S., RODIER, M., FILLON, L., FAURE, S. and CLERE, N. (2015). Epigallocatechin Gallate: A Review of Its Beneficial Properties to Prevent Metabolic Syndrome. Nutrients 7: 5443-5468.

LEUNG, L.K., SU, Y., CHEN, R., ZHANG, Z., HUANG, Y. and CHEN, Z.Y. (2001). Theaflavins in black tea and catechins in green tea are equally effective antioxidants. J Nutr 131: 2248-2251.

LI, G., ALEXANDER, H., SCHNEIDER, N. and ALEXANDER, S. (2000). Molecular basis for resistance to the anticancer drug cisplatin in Dictyostelium. Microbiology 146: 2219-2227.

LI, S.I. and PURUGGANAN, M.D. (2011). The cooperative amoeba: Dictyostelium as a model for social evolution. Trends Genet 27: 48-54.

LIAO, X.H., MEENA, N.P., SOUTHALL, N., LIU, L., SWAROOP, M., ZHANG, A.L., XIANG, J.J., PARENT, C.A., ZHENG, W. and KIMMEL, A.R. (2016). A HighThroughput, Multi-Cell Phenotype Assay for the Identification of Novel Inhibitors of Chemotaxis/Migration. Sci Rep 6: 22273.

LUDTMANN, M.H., OTTO, G.P., SCHILDE, C., CHEN, Z.H., ALLAN, C.Y., BRACE, S., BEESLEY, P.W., KIMMEL, A.R., FISHER, P., KILLICK, R. et al., (2014). An ancestral non-proteolytic role for presenilin proteins in multicellular development of the social amoeba Dictyostelium discoideum. J Cell Sci 127: 1576-1584.

MCQUADE, K.J., NAKAJIMA, A., ILACQUA, A.N., SHIMADA, N. and SAWAI, S. (2013). The green tea catechin epigallocatechin gallate (EGCG) blocks cell motility, chemotaxis and development in Dictyostelium discoideum. PLoS One 8: e59275.

MERIGHI, S., BENINI, A., MIRANDOLA, P., GESSI, S., VARANI, K., SIMIONI, C., LEUNG, E., MACLENNAN, S., BARALDI, P.G. and BOREA, P.A. (2007). Caffeine inhibits adenosine-induced accumulation of hypoxia-inducible factor-1alpha, vascular endothelial growth factor, and interleukin-8 expression in hypoxic human colon cancer cells. Mol Pharmacol 72: 395-406.

MIN, J., MESIKA, A., SIVAGURU, M., VAN VELDHOVEN, P.P., ALEXANDER, H., FUTERMAN, A.H. and ALEXANDER, S. (2007). (Dihydro)ceramide synthase 1 regulated sensitivity to cisplatin is associated with the activation of $\mathrm{p} 38$ mitogenactivated protein kinase and is abrogated by sphingosine kinase 1. Mol Cancer
Res 5: 801-812.

MIN, J., STEGNER, A.L., ALEXANDER, H. and ALEXANDER, S. (2004). Overexpression of sphingosine-1-phosphate lyase or inhibition of sphingosine kinase in Dictyostelium discoideum results in a selective increase in sensitivity to platinumbased chemotherapy drugs. Eukaryot Cell 3: 795-805.

MIN, J., TRAYNOR, D., STEGNER, A.L., ZHANG, L., HANIGAN, M.H., ALEXANDER, $\mathrm{H}$. and ALEXANDER, S. (2005a). Sphingosine kinase regulates the sensitivity of Dictyostelium discoideum cells to the anticancer drug cisplatin. Eukaryot Cell 4: 178-189.

MIN, J., VAN VELDHOVEN, P.P., ZHANG, L., HANIGAN, M.H., ALEXANDER, H. and ALEXANDER, S. (2005b). Sphingosine-1-phosphate lyase regulates sensitivity of human cells to select chemotherapy drugs in a p38-dependent manner. Mol Cancer Res 3: 287-296.

MONCHO-AMOR, V., GALARDI-CASTILLA, M., PERONA, R. and SASTRE, L. (2011). The dual-specificity protein phosphatase MkpB, homologous to mammalian MKP phosphatases, is required for $D$. discoideum post-aggregative development and cisplatin response. Differentiation 81: 199-207.

MOYA, P.R., MURPHY, D.L., MCMAHON, F.J. and WENDLAND, J.R. (2010). Increased gene expression of diacylglycerol kinase eta in bipolar disorder. Int $J$ Neuropsychopharmacol 13: 1127-1128.

MULLER-TAUBENBERGER, A., KORTHOLT, A. and EICHINGER, L. (2013). Simple system--substantial share: the use of Dictyostelium in cell biology and molecular medicine. Eur J Cell Biol 92: 45-53.

NEAL, E.G., CHAFFE, H., SCHWARTZ, R.H., LAWSON, M.S., EDWARDS, N., FITZSIMMONS, G., WHITNEY, A. and CROSS, J.H. (2009). A randomized trial of classical and medium-chain triglyceride ketogenic diets in the treatment of childhood epilepsy. Epilepsia 50: 1109-1117.

NIMH. (2017). Bipolar disorder: Statistics, ed. HEALTH, N. I. O. M.

OTTO, G.P., COCOROCCHIO, M., MUNOZ, L., TYSON, R.A., BRETSCHNEIDER, T. and WILLIAMS, R.S. (2016). Employing Dictyostelium as an Advantageous 3Rs Model for Pharmacogenetic Research. Methods Mol Biol 1407: 123-130.

OUERTATANI-SAKOUHI, H., KICKA, S., CHIRIANO, G., HARRISON, C.F., HILBI, H., SCAPOZZA, L., SOLDATI, T. and COSSON, P. (2017). Inhibitors of Mycobacterium marinum virulence identified in a Dictyostelium discoideum host model. PLoS One 12: e0181121.

PAFUMI, I., FESTA, M., PAPACCI, F., LAGOSTENA, L., GIUNTA, C., GUTLA, V., CORNARA, L., FAVIA, A., PALOMBI, F., GAMBALE, F. et al., (2017). Naringenin Impairs Two-Pore Channel 2 Activity And Inhibits VEGF-Induced Angiogenesis. Sci Rep 7: 5121

PANCHE, A.N., DIWAN, A.D. and CHANDRA, S.R. (2016). Flavonoids: an overview. J Nutr Sci 5: e47.

PASCHKE, P., KNECHT, D.A., SILALE, A., TRAYNOR, D., WILLIAMS, T.D., THOMASON, P.A., INSALL, R.H., CHUBB, J.R., KAY, R.R. and VELTMAN, D.M. (2018). Rapid and efficient genetic engineering of both wild type and axenic strains of Dictyostelium discoideum. PLoS One 13: e0196809.

PATSALOS, P.N. (2015). The clinical pharmacology profile of the new antiepileptic drug perampanel: A novel noncompetitive AMPA receptor antagonist. Epilepsia 56: $12-27$.

POLOZ, Y., CATALANO, A. and O'DAY, D.H. (2012). Bestatin inhibits cell growth, cell division, and spore cell differentiation in Dictyostelium discoideum. Eukaryot Cell 11: 545-557.

RAWANGKAN, A., WONGSIRISIN, P., NAMIKI, K., IIDA, K., KOBAYASHI, Y., SHIMIZU, Y., FUJIKI, H. and SUGANUMA, M. (2018). Green Tea Catechin Is an Alternative Immune Checkpoint Inhibitor that Inhibits PD-L1 Expression and Lung Tumor Growth. Molecules 23 (8).

REYMOND, C.D., SCHAAP, P., VERON, M. and WILLIAMS, J.G. (1995). Dual role of cAMP during Dictyostelium development. Experientia 51: 1166-1174.

ROBERY, S., MUKANOWA, J., PERCIE DU, S.N., ANDREWS, P.L. and WILLIAMS, R.S. (2011). Investigating the effect of emetic compounds on chemotaxis in Dictyostelium identifies a non-sentient model for bitter and hot tastant research. PLoS. One 6: e24439.

ROBERY, S., TYSON, R., DINH, C., KUSPA, A., NOEGEL, A.A., BRETSCHNEIDER, T., ANDREWS, P.L. and WILLIAMS, R.S. (2013). A novel human receptor involved in bitter tastant detection identified using Dictyostelium discoideum. J. Cell Sci 126: 5465-5476.

RODRIGUEZ DE TURCO, E.B., TANG, W., TOPHAM, M.K., SAKANE, F., MAR- 
CHESELLI, V.L., CHEN, C., TAKETOMI, A., PRESCOTT, S.M. and BAZAN, N.G. (2001). Diacylglycerol kinase epsilon regulates seizure susceptibility and long-term potentiation through arachidonoyl- inositol lipid signaling. Proc Natl Acad Sci USA 98: 4740-4745.

SAIKI, S., SASAZAWA, Y., IMAMICHI, Y., KAWAJIRI, S., FUJIMAKI, T., TANIDA I., KOBAYASHI, H., SATO, F., SATO, S., ISHIKAWA, K. et al., (2011). Caffeine induces apoptosis by enhancement of autophagy via PI3K/Akt/mTOR/p70S6K inhibition. Autophagy 7: 176-187.

SALEHI, B., FOKOU, P.V.T., SHARIFI-RAD, M., ZUCCA, P., PEZZANI, R., MARTINS N. and SHARIFI-RAD, J. (2019). The Therapeutic Potential of Naringenin: A Review of Clinical Trials. Pharmaceuticals (Basel) 12(1)

SEKINE, R., KAWATA, T. and MURAMOTO, T. (2018). CRISPR/Cas9 mediated targeting of multiple genes in Dictyostelium. Sci Rep 8: 8471.

SHARMA, D., OTTO, G., WARREN, E., BEESLEY, P., KING, J.S. and WILLIAMS, R.S.B. (2019). Gamma secretase orthologs are required for lysosomal activity and autophagic degradation in Dictyostelium discoideum, independent of PSEN (presenilin) proteolytic function. Autophagy 15: 11

SHIMSHONI, J.A., DALTON, E.C., JENKINS, A., EYAL, S., KWAN, K., WILLIAMS, R.S., PESSAH, N., YAGEN, B., HARWOOD, A.J. and BIALER, M. (2007). The effects of CNS-active Valproic acid constitutional isomers, cyclopropyl analogues and amide derivatives on neuronal growth cone behaviour. Mol. Pharmacol 71: 884-892.

SLEPIKAS, L., CHIRIANO, G., PEROZZO, R., TARDY, S., KRANJC, A., PATTHEYVUADENS, O., OUERTATANI-SAKOUHI, H., KICKA, S., HARRISON, C.F., SCRIGNARI, T. et al., (2016). In Silico Driven Design and Synthesis of Rhodanine Derivatives as Novel Antibacterials Targeting the Enoyl Reductase InhA. J Med Chem 59: 10917-10928.

STADELMAIER, R., NASRI, H., DEUTSCH, C.K., BAUMAN, M., HUNT, A., STODGELL, C.J., ADAMS, J. and HOLMES, L.B. (2017). Exposure to Sodium Valproate during Pregnancy: Facial Features and Signs of Autism. Birth Defects Res 109: 1134-1143.

SUSSMAN, M. (1987). Cultivation and synchronous morphogenesis of Dictyostelium under controlled experimental conditions. Methods Cell Biol 28: 9-29.

SWATSON, W.S., KATOH-KURASAWA, M., SHAULSKY, G. and ALEXANDER, S. (2017). Curcumin affects gene expression and reactive oxygen species via a PKA dependent mechanism in Dictyostelium discoideum. PLoS One 12: e0187562.

TAN, K.N., CARRASCO-POZO, C., MCDONALD, T.S., PUCHOWICZ, M. and BORGES, K. (2016). Tridecanoin is anticonvulsant, antioxidant, and improves mitochondrial function. J Cereb Blood Flow Metab 37: 13.

TARIQUL ISLAM, A.F.M., SCAVELLO, M., LOTFI, P., DANIEL, D., HALDEMAN, P. and CHAREST, P.G. (2019). Caffeine inhibits PI3K and mTORC2 in Dictyostelium and differentially affects multiple other cAMP chemoattractant signaling effectors. Mol Cell Biochem 457: 11.

TAYLOR, D. (2015). The Pharmaceutical Industry and the Future of Drug Development. In Issues in Environmental Science and Technology, vol. 41. Royal Society of Chemistry, pp.33.

TEMPLE, J.L., BERNARD, C., LIPSHULTZ, S.E., CZACHOR, J.D., WESTPHAL, J.A and MESTRE, M.A. (2017). The Safety of Ingested Caffeine: A Comprehensive
Review. Front Psychiatry 8: 80

TERBACH, N. and WILLIAMS, R.S. (2009). Structure-function studies for the panacea valproic acid. Biochem. Soc. Trans 37: 1126-1132.

THEIBERT, A. and DEVREOTES, P.N. (1983). Cyclic 3', 5'-AMP relay in Dictyostelium discoideum: adaptation is independent of activation of adenylate cyclase. J Cell Biol 97: 173-177.

TROFIMOV, V., KICKA, S., MUCARIA, S., HANNA, N., RAMON-OLAYO, F., DEL PERAL, L.V., LELIEVRE, J., BALLELL, L., SCAPOZZA, L., BESRA, G.S. et al., (2018). Antimycobacterial drug discovery using Mycobacteria-infected amoebae identifies anti-infectives and new molecular targets. Sci Rep 8: 3939.

VAN DRIESSCHE, N., ALEXANDER, H., MIN, J., KUSPA, A., ALEXANDER, S. and SHAULSKY, G. (2007). Global transcriptional responses to cisplatin in Dictyostelium discoideum identify potential drug targets. Proc Natl Acad Sci USA 104 15406-15411.

WAHEED, A., LUDTMANN, M.H., PAKES, N., ROBERY, S., KUSPA, A., DINH, C., BAINES, D., WILLIAMS, R.S. and CAREW, M.A. (2014). Naringenin inhibits the growth of Dictyostelium and MDCK-derived cysts in a TRPP2 (polycystin-2)dependent manner. Br. J. Pharmacol 171: 2659-2670.

WANG, H.Y. and FRIEDMAN, E. (1996). Enhanced protein kinase C activity and translocation in bipolar affective disorder brains. Biol Psychiatry 40: 568-575.

WARREN, E.C., WALKER, M.C. and WILLIAMS, R.S.B. (2018). All You Need Is Fats-for Seizure Control: Using Amoeba to Advance Epilepsy Research. Front Cell Neurosci 12: 199

WHO. (2017). The selection and use of essential medicines.

WHO. (2018). Cancer Fact Sheet.

WILLIAMS, R.S.B. and ANDREWS, P.L.R. (2019). Advice on avoiding the Valley of Death: insights from a 3Rs model of aversive and emetic compound identification. ALTEX 36(3): 466-469

WILLIAMS, R.S., BOECKELER, K., GRAF, R., MULLER-TAUBENBERGER, A., LI, Z., ISBERG, R.R., WESSELS, D., SOLL, D.R., ALEXANDER, H. and ALEXANDER, S. (2006). Towards a molecular understanding of human diseases using Dictyostelium discoideum. Trends Mol. Med 12: 415-424.

WILLIAMS, R.S.B. (2005). Prolyl oligopeptidase and bipolar disorder. Clin. Neurosci Res. 4: 233-242.

WILLIAMS, R.S.B., CHENG, L., MUDGE, A.W. and HARWOOD, A.J. (2002). A common mechanism of action for three mood-stabilizing drugs. Nature 417: 292-295.

WILLIAMS, R.S.B., EAMES, M., RYVES, W.J., VIGGARS, J. and HARWOOD, A.J. (1999). Loss of a prolyl oligopeptidase confers resistance to lithium by elevation of inositol $(1,4,5)$ trisphosphate. EMBO J 18: 2734-2745.

XU, X., MULLER-TAUBENBERGER, A., ADLEY, K.E., PAWOLLECK, N., LEE, V.W. WIEDEMANN, C., SIHRA, T.S., MANIAK, M., JIN, T. and WILLIAMS, R.S. (2007). Attenuation of phospholipid signaling provides a novel mechanism for the action of valproic acid. Eukaryot Cell 6: 899-906.

YIANNOPOULOU, K.G. and PAPAGEORGIOU, S.G. (2013). Current and future treatments for Alzheimer's disease. Ther Adv Neurol Disord 6: 19-33. 


\section{Further Related Reading, published previously in the Int. J. Dev. Biol.}

Overexpression of S-adenosylmethionine decarboxylase impacts polyamine homeostasis during development of Dictyostelium discoideum

Priyanka Sharma, Rishikesh Kumar and Shweta Saran

Int. J. Dev. Biol. (2018) 62: 647-652

https://doi.org/10.1387/ijdb.180167ss

Dictyostelium discoideum Sir2D modulates cell-type specific gene expression and is involved in autophagy Rakhee Lohia, Punita Jain, Mukul Jain, Pradeep Kumar Burma, Anju Shrivastava and Shweta Saran

Int. J. Dev. Biol. (2017) 61: 95-104

https://doi.org/10.1387/ijdb.160038ss

Pattern formation mechanisms in reaction-diffusion systems

Vladimir K. Vanag and Irving R. Epstein

Int. J. Dev. Biol. (2009) 53: 673-681

https://doi.org/10.1387/ijdb.072484vv

Dictyostelium discoideum: a model system for differentiation and patterning

R Escalante and J J Vicente

Int. J. Dev. Biol. (2000) 44: 819-835

http://www.intjdevbiol.com/web/paper/11206323

Cell-cell signaling and adhesion in phagocytosis and early development of Dictyostelium E Bracco, B Pergolizzi, B Peracino, E Ponte, A Balbo, A Mai, A Ceccarelli and S Bozzaro Int. J. Dev. Biol. (2000) 44: 733-742

http://www.intjdevbiol.com/web/paper/11061438

A cell type-specific effect of calcium on pattern formation and differentiation in dictyostelium discoideum

R Baskar, P Chhabra, P Mascarenhas and V Nanjundiah

Int. J. Dev. Biol. (2000) 44: 491-498

http://www.intjdevbiol.com/web/paper/11032184
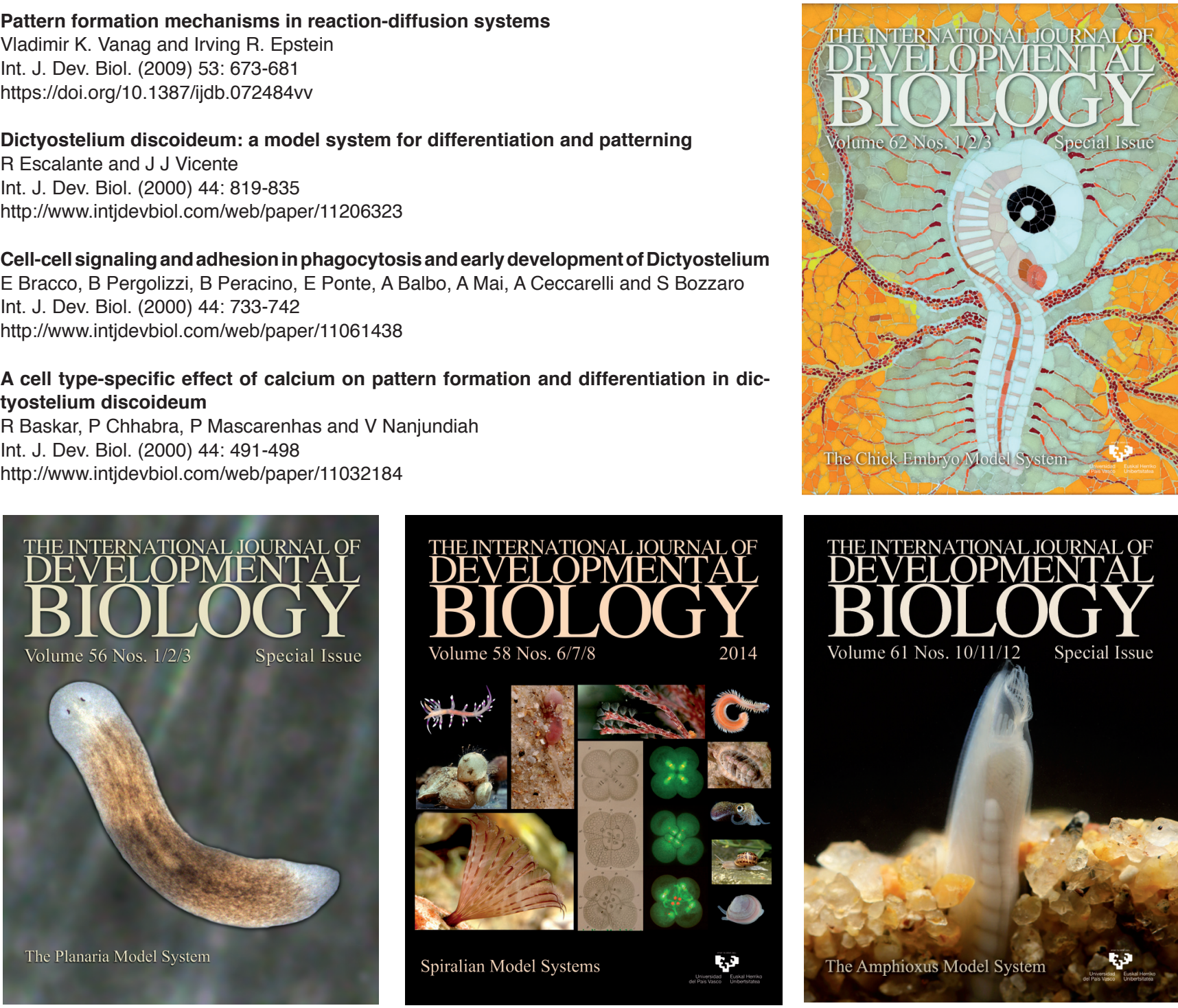